\title{
FRAGILE X SYNDROME
}

\section{CLINICAL, ELECTROENCEPHALOGRAPHIC AND NEUROIMAGING CHARACTERISTICS}

\author{
MARILISA M. GUERREIRO*, EDWALDO E. CAMARGO**, MERY KATO***, \\ ANTONIA P. MARQUES-DE-FARIA*, SYLVIA M. CIASCA*, CARLOS A.M. GUERREIRO*, \\ JOSE R. MENEZES NETTO ***, MARIA VALERIANA L. MOURA-RIBEIRO**
}

\begin{abstract}
We studied 11 patients ( 9 males) with cytogenetic diagnosis of fragile X syndrome (FXS) with the purpose of investigating the neural circuitry involved in this condition. The ages ranged from 8 to 19. All the individuals presented large ears, elongated faces and autistic features. Ten patients had severe mental retardation. Attention disorder was found in 10 individuals. Electroencephalographic recordings were abnormal in 6 of 10 patients examined, showing focal epileptiform discharges predominantly in frontal and parietal areas. All patients underwent magnetic resonance imaging studies which were abnormal in 8 of them. The most important abnormalities were reduction of the cerebellar vermis and enlargement of the IV ventricle. Single photon emission computerized tomography (SPECT) was performed in 7 patients and was abnormal in all of them, the most frequent finding being a hypoperfusion of the inferior portions of the frontal lobes. Based on the clinical picture, neuropsychological findings and functional and structural imaging studies we suggest that FXS presents with a dysfunction involving a large area of the central nervous system: cerebellum - basal frontal regions - parietal lobes. The literature points to a disturbance involving the same neural circuitry in patients with autism.
\end{abstract}

KEY WORDS: fragile X syndrome, MRI, SPECT, autism.

\section{Síndrome do $\mathrm{X}$ frágil: características clínicas, eletrencefalográficas e de imagem}

RESUMO - Estudamos 11 pacientes ( 9 do sexo masculino) com diagnóstico citogenético de síndrome do X frágil (SXF) com o objetivo de se investigar o circuito neuronal afetado nesta entidade. As idades variaram de 8 a 19 anos. Todos os indivíduos apresentaram pavilhões auriculares grandes, faces alongadas e traços autistas. Dez deles tinham retardo mental grave. Detectou-se a presença de distúrbio da atenção em 10 pacientes. O eletrencefalograma revelou-se anormal em 6 de 10 indivíduos examinados, mostrando descargas epileptiformes focais predominantemente em áreas frontais e parietais. Todos foram submetidos a ressonância magnética craniana que se revelou anormal em 8 . As anormalidades mais importantes foram redução do verme cerebelar e aumento do IV ventrículo. Realizou-se tomografia por emissão de photon único (SPECT) em 7 pacientes. Todos os exames estavam alterados sendo o principal achado a hipoperfusão das porções inferiores dos lobos frontais. Com base no quadro clínico, achados neuropsicológicos e resultados dos exames funcionais e de imagem, sugerimos que a SXF apresenta disfunção de ampla rede neuronal: cerebelo - regiões fronto basais - lobos parietais. A literatura aponta para a presença de distúrbio envolvendo o mesmo circuito neuronal em pacientes autistas.

PALAVRAS-CHAVE: síndrome do X frágil, RM, SPECT, autismo.

Departamentos de Neurologia, Radiologia e Genética Médica da Faculdade de Ciências Médicas (FCM) da Universidade Estadual de Campinas (UNICAMP): *Professor Assistente Doutor; **Professor Adjunto; ***Médico do Hospital das Clínicas da UNICAMP. Aceite: 10-dezembro-1997.

Dra. Marilisa Guerreiro - Departamento de Neurologia, FCM - UNICAMP - Caixa Postal 6111 - 13083-970 Campinas SP - Brasil. 
Fragile X syndrome (FXS) is one of the most common genetic etiologies of mental retardation ${ }^{1}$. The condition is characterized by a constriction (or fragile site) on the long arm of the $\mathrm{X}$ chromosome. The prevalence figure for affected males can be estimated to be one per $1250^{2}$. Physical features include an elongated face, large ears, prominent forehead, and macroorchidism, usually more pronounced in postpubertal affected males. At least one-third of female heterozygotes present clinical manifestations which are similar in quality but lesser in severity than those seen in males with this condition $^{3}$. Evidence suggests that there is a correlation between FXS and autism since almost all FXS patients exhibit autistic characteristics. Typical behavior includes poor eye contact, tactile defensiveness, hand flapping, hand biting, perseverative speech, hyperactivity and a short attention span. Therefore, many authors consider FXS as a biological model to study autism ${ }^{4-8}$.

The purpose of this study was to evaluate the neurological, behavioral, neuropsychological and neuroimaging aspects of a group of patients with FXS and to correlate these findings in order to investigate the neural circuitry involved in the syndrome. We also wished to compare the findings in our patients with FXS with those reported in children with autism.

\section{PATIENTS AND METHODS}

Eleven patients ( 9 males, 2 females), aged 8 to 19 years with cytogenetic diagnosis of FXS were submitted to:

- Clinical and neurological evaluation;

- Psychometric assessment with application of Wechsler Intelligence Scale for Children (WISC) ${ }^{9}$, and the Gestalt Test of Bender ${ }^{10}$;

- Neuropsychiatric evaluation of behavior according to clinical assessment following the criteria presented by the Manual of Statistical Diagnosis (DSM-III-R) ${ }^{11}$;

- Neurosychological evaluation through an assessment battery adapted from Mental State Assessment by Weintraub and Mesulam ${ }^{12}$, which estimated attention (attention disorder was considered present if the patient had impersistence and/or perseveration), language, memory, praxis, gnosis, and complex tasks;

- Electroencephalogram (EEG). The tracings were taken only under induced sleep with chloral hydrate due to lack of cooperation; all patients had 16-channel EEGs with the international 10-20 electrode system;

- Study of the cerebral perfusion using single photon emission computerized tomography (SPECT) imaging with the administration of $15 \mathrm{mCi}(740 \mathrm{MBq})$ of HMPAO-99mTc while resting. SPECTs were interpreted by two experts, comparing qualitatively with normal exams and taking quantitative measures to have more accurate data;

- Magnetic resonance imaging (MRI) using a General Electric 1.5 Tesla Sigma Scanner. The patients were under anesthesia. Scans were interpreted by one expert, comparing qualitatively with normal exams.

\section{RESULTS}

All patients presented elongated face and large ears (Fig 1). Macroorchidism was found in 3 male patients. Ten patients had severe mental retardation and one, moderate mental retardation. Autistic features were found in all patients: poor eye contact was observed in 10/11 patients, stereotypic movements in $8 / 11$, hyperactivity in $9 /$ 11 , hand biting in 3/11, perseverative speech in $9 / 11$ and speech delay in all 11 patients. Neurological evaluation revealed Babinski sign in 5 patients $(45.4 \%)$, hyperreflexia in 4 (36.3\%), divergent strabismus in $3(27.2 \%)$, head circumference alteration in $2(18.1 \%)$, one with microcephaly and one with macrocephaly, hypotonia in 2 $(18.1 \%)$ and neuromotor developmental delay in $8(72.7 \%)$.

Four patients (36.3\%) had epilepsy, one had febrile seizure and one had one single unprovoked seizure. All epileptic patients have their seizures controlled with antiepileptic drugs.

Neuropsychological evaluation revealed attention disorder in 10 individuals and one patient did not cooperate with the examination. We found impersistence in 10 patients $(90.9 \%)$ and perseveration in $6(60 \%)$. All 11 patients were able to perform simple memory, praxis, gnosis and constructional tasks. All patients had comprehension difficulty. All but one patient were right handed.

Ten patients had EEG which showed frontal and parietal epileptiform discharges in 6 (Table 1).

MRI was done in all individuals and was abnormal in 8 of them, mainly a reduction of the cerebellar vermis and enlarged IV ventricle (Fig 2). SPECT revealed cerebral blood flow alterations in all 7 patients who underwent this exam, mostly hypoperfusion of the inferior portions of the frontal lobes (Fig 3 ). The neuroimaging results are shown in Table 2. 


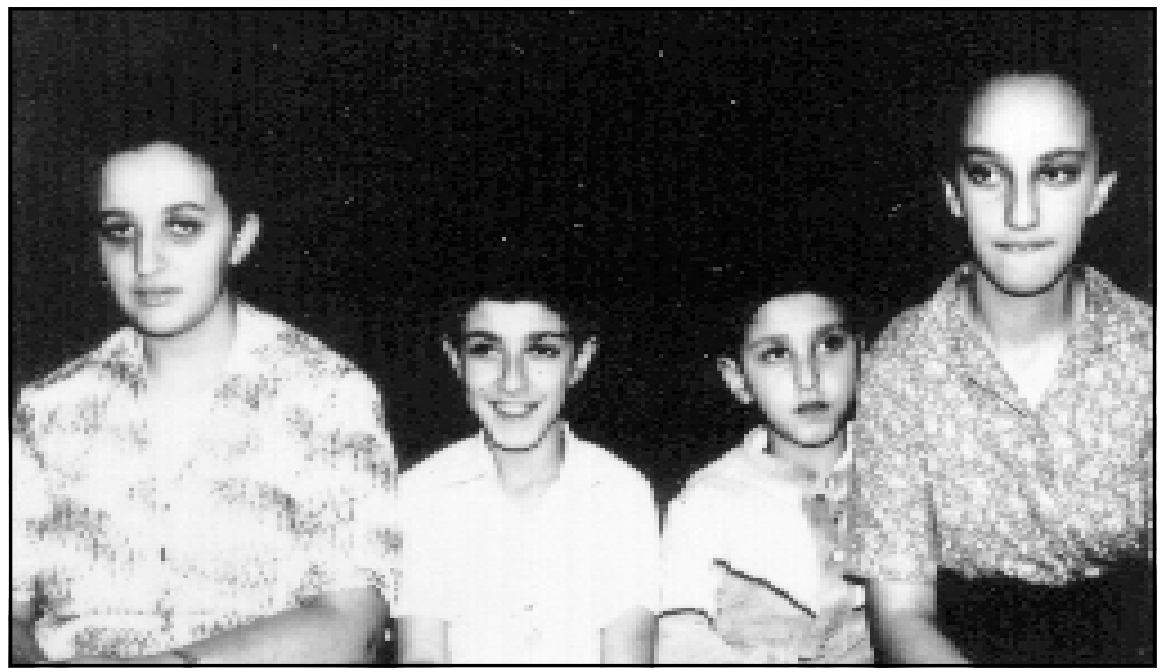

Fig 1. One family with the fragile X chromosome. Note the elongated face, large ears and prominent forehead.

Table 1. Fragile-X syndrome: epileptic and EEG findings.

\begin{tabular}{ccc}
\hline Patient & Seizure manifestation & EEG \\
\hline 1 & - & Normal \\
2 & 2 Complex febrile seizures & Normal \\
3 & - & Normal \\
4 & CPSs & Normal \\
5 & 1 GTCS + 1 CPS & Left and right spikes in frontal and parietal regions \\
6 & 1 GTCS & Left frontal and parietal sharp waves \\
7 & - & GSWC + right frontal and parietal sharp waves \\
8 & - & GSWC maximum in left frontal region \\
9 & 1 Febrile seizure + SE + 2 TCS & Right and left frontal sharp waves \\
10 & Several types of seizures & GSWC+left and right parietal and occipital spikes \\
11 & - & Not done \\
\hline
\end{tabular}

CPS, complex partial seizure; GTCS, generalized tonic-clonic seizure; SE, generalized status epilepticus; GSWC, generalized spike-wave complex.

\section{DISCUSSION}

Our data suggest that there is a similarity between autism and FXS, as the results showed that our patients exhibit many autistic characteristics.

Neuropsychological evaluation revealed short attention span in 10 patients and impaired comprehension in all of them. Every patient showed speech delay. Failure to acquire speech at the expected age and impaired comprehension of language are frequent findings in autistic children ${ }^{13,14}$. 


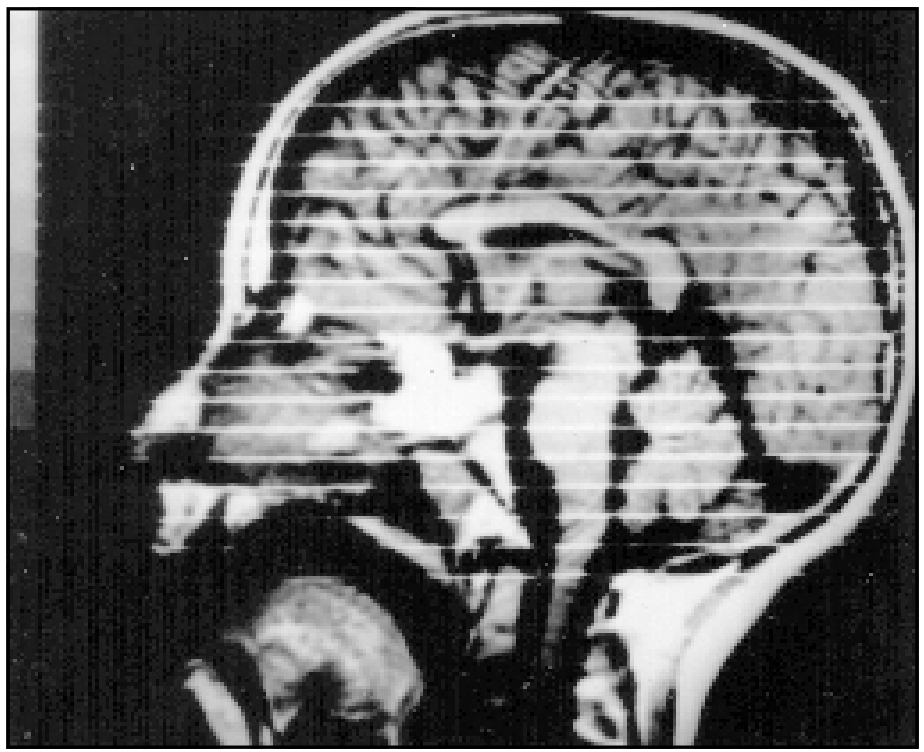

Fig 2. MRI of patient 5 shows reduction of cerebellar vermis and enlargement of IV ventricle.

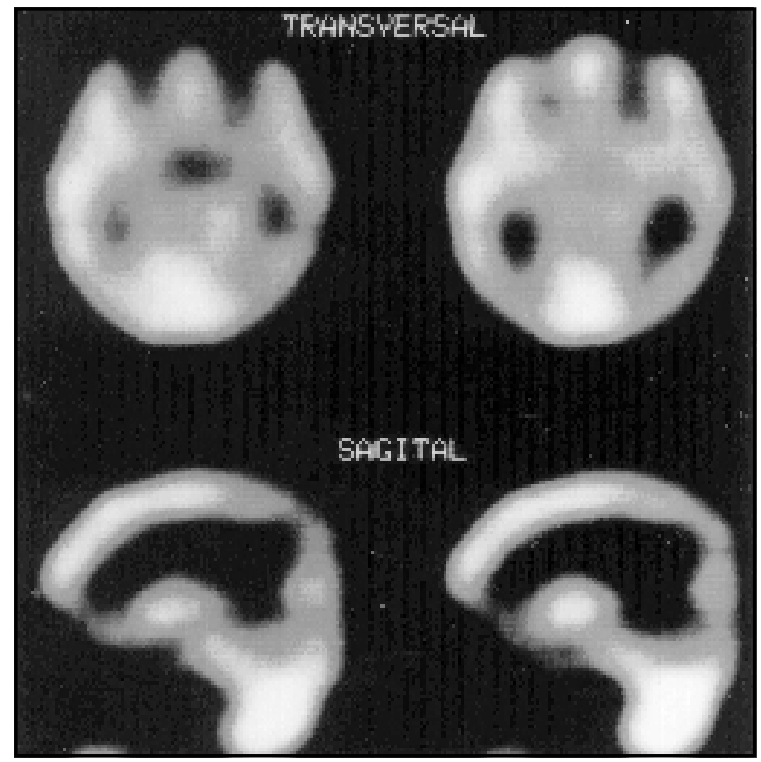

Fig 3. SPECT of patient 10 shows hypoperfusion of frontal and parietal regions.

The attention tasks were poorly performed. A disturbance of the attentional matrix results in impersistence and perseveration ${ }^{12}$, common findings in this study. Other authors found attention deficit disorder in $\mathrm{FXS}^{7,8,15-17}$ and it is considered that virtually all autistic children have some type of attention disorder ${ }^{14}$. So, the neuropsychological results in our patients are further evidence for similar behavioral manifestations in autism and FXS. 
Table 2. Fragile-X syndrome: neuroimaging results.

\begin{tabular}{ccc}
\hline Patient & MRI & SPECT \\
\hline 1 & $\downarrow$ Vermis & Cerebellar Hypop. \\
2 & $\uparrow$ IV & Cerebellar, Front. Hypop. \\
3 & $\uparrow$ Lat. & Inconclusive \\
4 & Normal & Inconclusive \\
5 & $\downarrow$ Vermis and $\uparrow$ IV & NC \\
6 & $\downarrow$ Vermis and $\uparrow$ IV & NC \\
7 & Normal & Front. Hypop. \\
8 & Normal & Front., Par., Occip. Hypop. \\
9 & $\downarrow$ Vermis and $\uparrow$ IV & Front. Hypop. \\
10 & $\downarrow$ Vermis and $\uparrow$ IV & Front., Par. Hypop. \\
11 & $\downarrow$ Vermis & Front. Hypop. \\
\hline
\end{tabular}

$\downarrow$ Vermis, hypoplasia of the vermis of cerebellum; $\uparrow$ IV, enlarged IV ventricle; $\uparrow$ Lat., enlarged lateral ventricles; Hypop., hypoperfusion; Front., inferior portions of frontal lobes; Par., parietal lobes; Occip., occipital lobes; NC, patient non-cooperative.

Attention difficulties, perseverative speech and behavior, and hyperactivity have been considered frontal lobe deficits, since this cortical region is the most intimately related to the maintenance of the attentional matrix ${ }^{18,19}$. Patients with frontal lobe lesions commonly show deficits in tests that are known to be sensitive to attentional disturbances. The neural network of directed attention contains a frontal representation, a posterior parietal cortex representation and a reticular representation that provides a tone for the attentional matrix ${ }^{18}$. Physiologic studies in autistic children such as PET have revealed abnormalities of the cerebral cortex and, in particular, of association cortex (frontal and parietal lobes) ${ }^{20,21}$. Some investigators have noted that the PET abnormalities involve the neural circuitry for selective attention and have proposed primary dysfunction in the cortical mechanisms for selected attention in autism ${ }^{22,23}$. Brain SPECT imaging in our study revealed mainly hypoperfusion of the inferior portions of the frontal lobes and hypoperfusion of the parietal lobes in a few patients. Our data reinforce the involvement of the frontal and parietal lobes in the neural circuitry of the attentional network in the FXS. Our findings agree with those of the literature in autism ${ }^{20-23}$.

In this study, the EEG showed focal epileptiform discharges in $60 \%$ of the cases, predominantly in the frontal and parietal areas. The EEG findings in our patients agree with the SPECT data and also point to a disturbance involving the neural circuitry responsible for the attention span.

Four of our patients were epileptic and all of them were controlled with antiepileptic drugs. Other investigators have also noted the benign course of epilepsy and the good response to the treatment in FXS patients ${ }^{8,17,24-26}$.

The MRI was abnormal in 8 patients, showing mainly a reduction of cerebellar vermis and enlargement of the IV ventricle. Reiss et al. ${ }^{3,27,28}$ have done neuroanatomic studies with MRI in FXS patients and also have found a reduction of cerebellar vermis and an enlargement of the IV ventricle when comparing to a control group. Courchesne et al..$^{29,30}$ have observed the same findings in autistic patients. These authors suggest that cerebellar vermis dysfunction may play a prominent role in the development of the autistic behavior. Another possibility is that the cerebellar vermis may modulate attention through the connections with the reticular system of the brainstem which is part of the attention neural circuitry. 
In conclusion, based on the neuropsychological findings as well as on functional and structural imaging tests, we suggest the involvement of a large network in the FXS: cerebellum - basal frontal regions - parietal lobes.

We also conclude that brain SPECT and MRI imaging are useful techniques that contribute to the understanding of the neurological basis of the FXS.

Acknowledgements - The authors thank Dr. Fernando Cendes for reviewing the manuscript.

\section{REFERENCES}

1. Oostra BA, Halley DJJ. Complex behavior of simple repeats: the fragile X syndrome. Pediatr Res 1995;38:629-637.

2. Brown WT. The FRAXE syndrome. Am J Hum Genet 1996;58:903-905.

3. Reiss AL, Freund L, Tseng LE, Joshi PK. Neuroanatomy in fragile X females: the posterior fossa. Am J Hum Genet 1991;49:279-288.

4. Blomquist HK, Bohman M, Edvinsson SO, et al. Frequency of the fragile X syndrome in infantile autism: a Swedish multicenter study. Clin Genet 1985;27:113-117.

5. Borghgraef M, Fryns JP, Dielkens A, Pyck K, Van Der Berghe H. Fragile X syndrome: a study of the psychological profile in 23 prepubertal patients. Clin Genet 1987;32:179-186.

6. Brown WT. The fragile X syndrome. Neurol Clin 1989;7:107-121.

7. Johnson VP, Carpenter NJ, Skorey PA. Martin-Bell syndrome segregating in a large kindred with normal transmitting males: clinical, cytogenetic, and linkage study. Am J Med Genet 1991;38:275-282.

8. Vieregge P, Froster-Iskenius U. Clinico-neurological investigations in the fra(X) form of mental retardation. J Neurol 1989;236:85-92.

9. Wechsler Intelligence Scale for Children, 5.Ed. Translated and adapted 1949, 1980. New York: Psychological Corporation, 1991.

10. Clawson A. Bender infantil: manual de diagnóstico clínico. 6.Ed. Tradução por Jurema Alcides Cunha. Porto Alegre: Artes Médicas, 1991.

11. American Psychiatric Association. Diagnostic and statistical manual of mental disorders, 3.Ed. Washington, DC: American Psychiatric Association, 1987.

12. Weintraub S, Mesulam M-M. Mental state assessment of young and elderly adults in behavioral neurology. In Mesulam MM (ed). Principles of behavioral neurology. Philadelphia: F.A. Davis, 1985:71-123.

13. Rapin I. Autistic children: diagnosis and clinical features. Pediatrics 1991;87(Suppl):751-760.

14. Rapin I, Mattis S, Rowan AJ, Golden GG. Verbal auditory agnosia in children. Develop Med Child Neurol 1977;19:192-207.

15. Mazzocco MMM, Hagerman RJ, Pennington BF. Problem solving limitations among cytogenetically expressing fragile $X$ women. Am J Med Genet 1992;43:78-88.

16. Steyaert J, Borghgraef M, Gaulthier C, Fryns JP, Van Der Berghe H. Cognitive profile in adult, normal intelligent female fragile X carriers. Am J Med Genet 1992;43:116-119.

17. Wisniewski KE, Segan SM, Miezejeski CM, Sersen EA, Rudelli RD. The fra(X) syndrome: neurological, electrophysiological, and neuropathological abnormalities. Am J Med Genet 1991;38:476-480.

18. Mesulam M-M. Attention, confusional states, and neglect. In Mesulam M-M (ed). Principles of behavioral neurology. Philadelphia: F.A. Davis, 1985:125-168.

19. Mesulam M-M. Large-scale neurocognitive networks and distributed processing for attention, language, and memory. Ann Neurol 1990;28:597-613.

20. Horwitz B, Rumsey J, Grady C, Duara R, Schapiro M, Rapoport J, Rapoport S. Interregional correlations of glucose utilization among brain regions in autistic adults (Abstr). Ann Neurol 1987;22:118.

21. Horwitz B, Rumsey JM, Grady CL, Rapoport SI. The cerebral metabolic landscape in autism: intercorrelations of regional glucose utilization. Arch Neurol 1988;45:749-755.

22. Minshew NJ. Indices of neural function in autism: clinical and biologic implications. Pediatrics 1991;87(Suppl):774-780.

23. Minshew NJ, Pettegrew JW, Payton JB, Panchalingam K. Metabolic alterations in the dorsal prefrontal cortex of autistic patients with normal IQ (Abstr). Ann Neurol 1989;26:438.

24. Finelli PF, Pueschel SM, Padre-Mendoza T, O’Brien MM. Neurological findings in patients with the fragile-X syndrome. J Neurol Neurosurg Psychiatry 1985;48:150-153.

25. Musumeci SA, Ferri R, Elia M, Colognola RM, Bergonzi P, Tassinari CA. Epilepsy and fragile X syndrome: a follow-up study. Am J Med Genet 1991;38:511-513.

26. Wisniewski KE, French JH, Fernando S, et al.. Fragile X syndrome: associated neurological abnormalities and developmental disabilities. Ann Neurol 1985;18:665-669.

27. Reiss AL, Aylward E, Freund LS, Joshi PK, Bryan RN. Neuroanatomy of fragile X syndrome: the posterior fossa. Ann Neurol 1991;29:26-32.

28. Reiss AL, Freund L. Fragile X syndrome. Biol Psychiatry 1990;27:223-240.

29. Courchesne E. Neuroanatomic imaging in autism. Pediatrics 1991;87(Suppl):781-790.

30. Courchesne E, Yeung-Courchesne R, Press GA, Hesselink JR, Jernigan TL. Hypoplasia of cerebellar vermal lobules VI and VII in autism. N Engl J Med 1988;318:1349-1354. 